\title{
Assessment of the Current State of Qanibay al-Rammah Complex (908 AH/1502 AD), as a Procedure Precedes the Restoration Process
}

\author{
Essam H. Mohamed $(\mathbb{0}$ \\ Archaeological Conservation Department, Faculty of Archaeology, South Valley University, Qena, Egypt \\ Email: essam.mohamed@arch.svu.edu.eg
}

How to cite this paper: Mohamed, E.H. (2020) Assessment of the Current State of Qanibay al-Rammah Complex (908 AH/1502 $\mathrm{AD})$, as a Procedure Precedes the Restoration Process. Open Journal of Geology, 10, 71-91.

https://doi.org/10.4236/ojg.2020.101004

Received: December 3, 2019

Accepted: January 7, 2020

Published: January 10, 2020

Copyright (c) 2020 by author(s) and Scientific Research Publishing Inc. This work is licensed under the Creative Commons Attribution International License (CC BY 4.0).

http://creativecommons.org/licenses/by/4.0/

\begin{abstract}
An assessment should be made of the current state of the historic buildings before starting in any intervention procedures. Where, any procedures of conservation of the building must be outrun by a perfect diagnosis according to the international conventions. Chemical, physical, mechanical properties and structural status are extremely important to give information about the current condition of Qanibay al-Rammah madrasa, which situated within Saladin square in Historic Cairo. This building has been affected by several deterioration factors since the construction and still suffering damage factors at the moment, which led to the occurrence of several damage aspects to the building, such as fissures in architectural elements, granular disintegration, loss of stone material, peeling of limestone surface, splitting in building material, the efflorescence of salts, pitting in limestone surface, black spots in stone surface, hard black crust, etc. The aim of this study is evaluation of the condition of Qanibay al-Rammah madrasa by two methods, firstly by different scientific techniques such as X-Ray Diffraction (XRD), EDX analytical methods, Scanning Electron Microscopy (SEM), Polarizing Light Microscopy (PLM), and Stereo Microscopy, and secondly by Numerical analysis based on 3D finite elements analysis to determine the critical places of the building. The followed methodology in this study allowed us to the assessment of the current status of the building by various scientific techniques to determine the real causes of damage, which must be taken into account during the intervention procedures.
\end{abstract}

\section{Keywords}

Madrasa of Qanibay al-Rammah, The Current Status, Building Materials Characteristics, Structural Behavior, Scientific Techniques, Numerical Analysis 


\section{Introduction}

Limestone is considered the most important stone which has been widely used in historic Cairo's buildings on throughout history; Mokattam, Tora and Maasara quarries are considered the most important quarries that played a major role in construction of archaeological buildings in ancient Egypt [1]. Several researches conducted on limestone used in most of the Islamic archaeological buildings in historic Cairo confirmed that they date back to the middle Eocene. This kind of limestone was used as a major building material in madrasa of Qanibay al-Rammah which situated in Saladin square, Historic Cairo. The major building material (limestone) used in case study has been suffering from several deterioration factors such as effect of saturated soil with contaminated water, groundwater raised, air pollution, microbiological deterioration, urban trespasses and man-made destruction, variation between temperature and relative humidity; it is also suffering damage factors and causes at the moment. Wet and dry cycles cause complex mechanical damage in particular when salts are found in the pores of limestone; because the limestone is characterized by high porosity, so it has ability to absorb moisture from air or ground, thus facilitating penetration of salts spray into its components causing physiochemical damage, especially when the dissolved salts turn to different crystalline sizes, causing cracks in internal structure of the stone due to internal pressures [2] [3]. Water saturated with salts seeping into the pores of building materials causes the loss of mechanical strength [4] [5]. When water evaporation occurs the salts recrystallize within the pores of the stone resulting in significant pressure on the pore walls from the inside which leads to cracks in the internal structure of the stone resulting in fall of some parts of the stone [6]. The rate of damage is more serious in urban areas because amount of $\mathrm{SO}_{2}$ which is generated by humanitarian activities far exceeds the quantities from natural sources, which leads to the speed of damage of archaeological buildings located in urban areas. As such found in the case study [7] [8], the interaction between air pollution gases and building materials leads to the formation of black hard crust on the surface of the stone; this causes loss of stone material due to the physiochemical interactions between the stone components and acid gases [9] [10]. The wind has a very big role in limestone damage as it works to increase the rate of evaporation of salt solutions inside the stone pores, which helps the efflorescence of salts on the surface [11]; in addition to the destructive impact of groundwater on building materials, it helps the growth of microorganisms that produce different types of organic acids such as carbonic, oxalic, sulfuric and nitric acids [12]. These acids interact with the mineral components of limestone leading to its degradation, microorganisms cause of physical changes in the size of stone pores, as well as changes occur in water distribution in the chemical composition of stone surfaces, leading to a weak internal structure of mineral crystals [13] [14]. Structural damage causes of monuments are showing in three of the problems that effect on the buildings, namely: seismic action, soil differential settlement owing to the variability of the 
groundwater table, and material deterioration [15].

Madrasa of Qanibay al-Rammah has been suffering damage factors and causes since ancient times because of the old earthquakes and raised groundwater level, it is also suffering damage factors and causes at the moment.

The present research study has been oriented by the following hypothesis:

- According to international conventions, the building must be evaluated by the different scientific techniques before intervention procedures.

- Assessment of current state of the building gives an indication of different properties of building materials and structural behavior as well as the physical condition of the building.

- The current status report resulting from the evaluation process refers to the identification and classification of deterioration symptoms of building materials.

- Optimal assessment of building materials enables us to use appropriate restoration methods for the condition of the building.

- Strategies, policies, and objectives that achieve conservation of the buildings as a historical and archaeological value should be preceded by the study and identification of problems and risks that threaten these buildings; this is achieved through the evaluation of building materials.

- Intervention procedures of restoration methods are based on the current status report of the building.

\section{Qanibay al-Rammah Complex}

Qanibay al-Rammah complex at Saladin square was inscribed as a World Heritage Site (UNESCO) in 1979 as a part of Historic Cairo. This madrasa was established by Prince Qanibay Amir Akhur in 908 AH/1502 AD in the Sultanate of Qansuh al-Ghuri (1501-1516 AD) at Saladin square which considered of the suspended schools, their layout follows iwan style, it has two facades, the first is at the eastern side where there is a door leading to a building that was annexed to the school. The second façade at the southern side is the main one and overlooks a yard between this mosque and al-Mahmudiyya Mosque and includes the dome, the minaret, the sabil, the kuttab and the main entrance which is high and ascended to by stairs leading to the door of the mosque, this mosque consists of a courtyard on which, four iwans are perpendicular. The southeastern iwan is the biggest and is covered with three vaults. It is clear from the madrasa design integration of elements and balance as well as the good distribution of elements according to their function and relationship to each other (Figure 1).

\subsection{Building Materials Characterization}

Limestone is considered the main building material which was used in construction of Qanibay al-Rammah madrasa, addition to different types of marble, which were used as casing on walls of building and lime-gypsum mortar used as bind materials. 


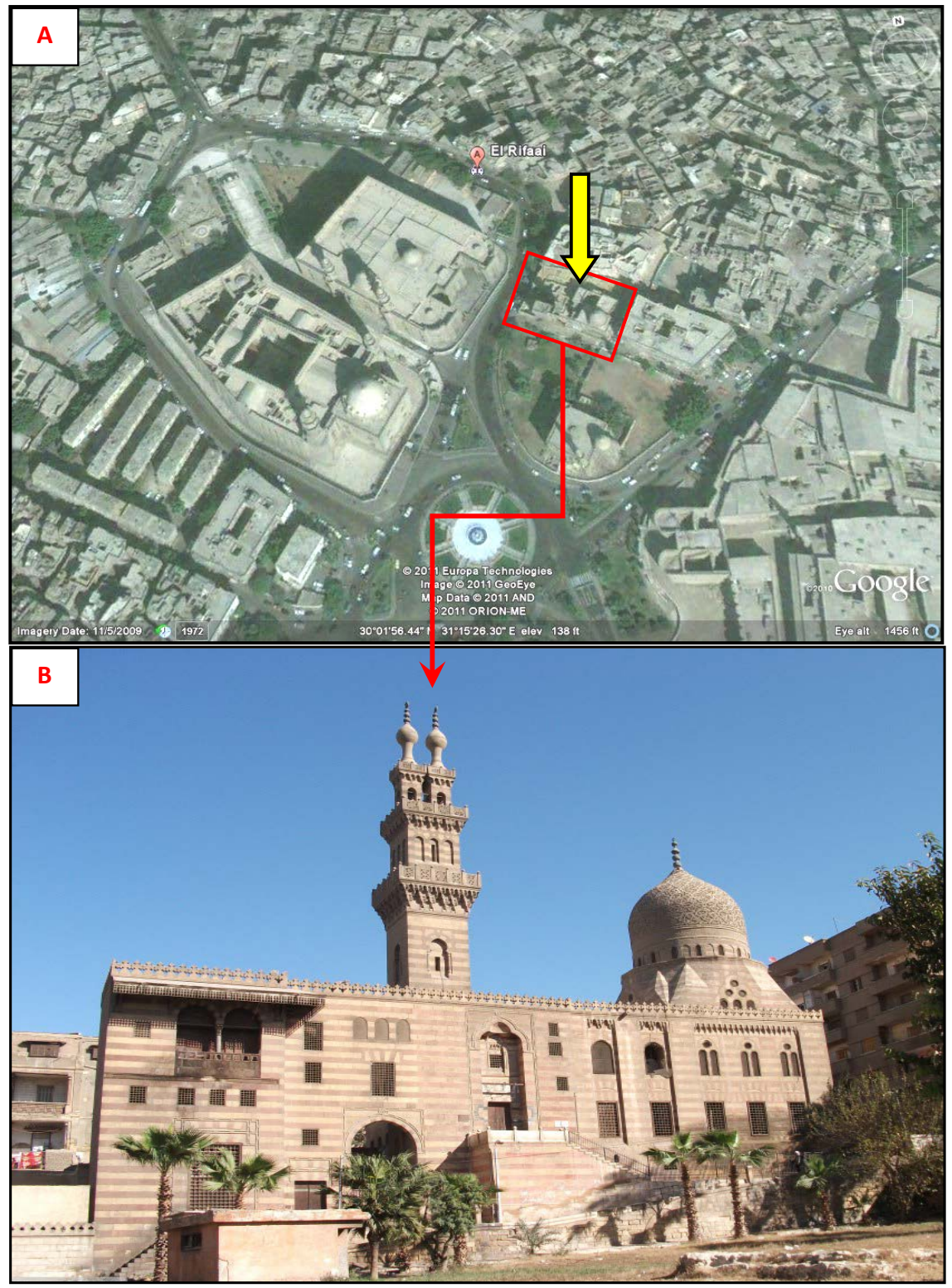

Figure 1. (A) Site of Qanibay al-Rammah complex in Saladin square, it is noted that there is an urban density (Satellite); (B) The main façade of the building.

Limestone used in case study consist of fine grains of calcite crystals, amorphous carbonates, low percentages of dolomite, fine quartz crystals and gypsum, it is characterized by dark yellow, cream or gray color, high hardness, free of impurities and low porosity, the stone contains various types of fossils such as Nummulite, Foraminifera, Bryozoa echinoid, and Bivalve [16]. The marble used in case study varies between white, red and green which used as casing of the shrine walls; it is characterized by fine grains of calcite, dolomite crystals in rather variable proportions, with considerable to moderate contents of biotite, quartz, brucite, ankerite, chlorite and anorthite, on another side mortars used in building consist of a cementations binder, fine aggregate, sand as filler materials, which were used as binding material in the joints of the courses of building 
walls, also play a role in distributing compressive strength between walls.

\subsection{Present Condition of the Studied Building}

The building materials have been suffering from several deterioration factors such as raise ground water level, effect of saturated soil with contaminated water, air pollution, variation between temperature and relative humidity, microbiological deterioration, urban trespasses, effect of earthquakes and man-made destruction, it is also suffering damage factors and causes at the moment such as ground water raised, urban trespasses, pollution and infection of ground water beneath the building soil. The ground water are contained various types of mineral salts, in which they are the most important physiochemical weathering and damage processes that affected on the building materials. When the water bearing salts evaporate, the salts crystallize inside the pores of building materials, resulting in pressure occur inside the pores leading to cracks occur in the material's structure. Also continuous changes in temperature and relative humidity leads to occur a complex damage mechanism that effects on the different properties of building materials [17] [18] [19]. Volume of these materials is changing with expansion and contraction resulting in decays the building materials on long term [20]. The occurrence of acid rain on building materials surfaces cause of chemical reactions drive to degradation of building materials [21]. When the water is withdrawn from the soil through the pores, it reacts with the bonding materials of the stone. As a result of water evaporation, the interaction products are deposited on the stone surface, because of the continuous loss of the bonding materials of the mineral crystals, external crust forms in the stone's surface, when it falls down the stone exposes to continuous bleeding from the granules [22] [23]. In the case of presence of microorganisms on building materials surfaces, it produces acids such as oxalic, lactic, glycolic, citric, nitric, sulfuric which interaction with building materials leading to damage it. Microbiological damage factors contribute in weathering of building materials when suitable environmental conditions are available, such as temperature, humidity, light and food, taking into account the different properties of the stone [24] [25] [26]. The building was exposed to structural problems as a result of its foundation on rubbish fill soil, which affected by the high level of the groundwater jointly with the impact of horizontal and vertical displacement resulting from seismic activity, which led to an irregular settlement of the soil, and fissures have occurred in the structural elements of the building (Case study). Identification, classification, evaluation of weathering forms on building materials used in the case study were carried out according to classify of German geological scientist Fitzner [27], where the weathering forms classified into four main groups: 1-Loss of stone material (LS), 2-Deposits (DD) Discoloration, 3-Detachment of stone material (DT), 4-Fissures/Deformation (FD), and each group is divided into sub-groups (Table 1 and Figure 2). Through the field study, the several deterioration aspects of limestone (the main material) used in the case study were detected such 
Table 1. Identification, classification, evaluation of weathering forms on building materials of the case study.

\begin{tabular}{|c|c|c|c|c|c|c|c|c|c|c|c|c|c|c|c|c|c|c|}
\hline \multirow{2}{*}{ 放 } & \multicolumn{3}{|c|}{ Group 1} & \multicolumn{4}{|c|}{ Group 2} & \multicolumn{9}{|c|}{ Group 3} & \multicolumn{2}{|c|}{ Group 4} \\
\hline & $\mathrm{W}$ & $\mathbf{R}$ & $\mathrm{O}$ & $\mathrm{D}$ & I & $\mathrm{E}$ & $\mathrm{C}$ & G & $\mathbf{P}$ & $\mathrm{F}$ & $S$ & $\mathrm{~K}$ & G-F & G-P & F-P & P-S & F-S & $\mathrm{L}$ \\
\hline \multicolumn{19}{|l|}{1} \\
\hline 2 & & & & & & & & & & & & & & & & & & \\
\hline \multicolumn{19}{|l|}{3} \\
\hline \multicolumn{19}{|l|}{4} \\
\hline \multicolumn{19}{|c|}{5} \\
\hline \multicolumn{19}{|l|}{6} \\
\hline \multicolumn{19}{|l|}{7} \\
\hline & \multicolumn{18}{|c|}{$\begin{array}{l}\text { 1-Southern west façade, } 2 \text {-Southern east façade, 3-Northern west façade, } \\
\text { ern east Iwan, 5-Northern east Iwan, 6-Southern west Iwan, 7-Northern west Iwan. }\end{array}$} \\
\hline & \multicolumn{3}{|c|}{ No occurring } & \multicolumn{4}{|c|}{ Very slight damage } & \multicolumn{3}{|c|}{ Slight damage } & \multicolumn{3}{|c|}{ Moderate damage } & \multicolumn{3}{|c|}{ Severe damage } & \multicolumn{2}{|c|}{ Very Severe. } \\
\hline
\end{tabular}

1- Loss of stone material (Ls)

Back weathering (W)

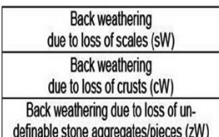

acck weathering due toloss of un-

finable stone aggregates/pieces $2 \mathrm{ZW}$
Break out (O)

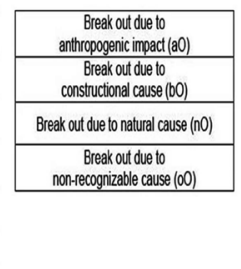

3- Detachment of stone material (DT)

2- Discoloration/deposits (DD)

Discoloration (D)

Soiling (I)
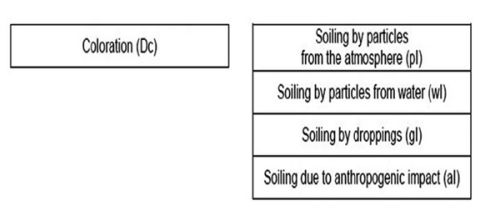

4- Fissure/Deformation (FD)

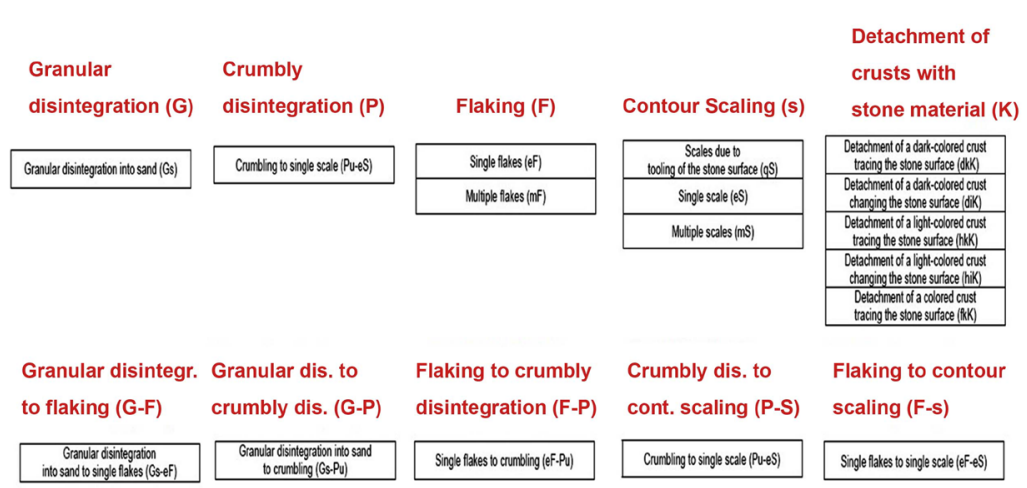

Fissures (L)

\begin{tabular}{c} 
Fissures \\
independent of stone structure (VL) \\
\hline Fissures \\
dependent on stone structure (tL) \\
\hline
\end{tabular}

Figure 2. Main and sub groups of weathering forms.

as; efflorescence salts, granular disintegration into powder, separation of crusts or thin sheets of stone surface this phenomenon is known as back weathering, hard black crust on stone surface due to effect of air pollution, loss of stone material, exfoliation, bleeding of stone, fissures, cracks and chipping off pieces, 
spots on the stone surface ranging from brown, black, red and green, relief, and pitting on the limestone surface (Figure 3).

\section{Properties of the Building Materials Used in the Case Study}

Besides current conditions of the building materials of Qanibay al-Rammah madrasa that determined by visual observation, physical, chemical and mechanical properties were investigated by laboratory studies, stones (limestone, marble) and mortars were collected from the deteriorated parts of the building. In order to assessment of building materials properties used in case study, physical properties tests, such as bulk density, water absorption, porosity, and mechanical

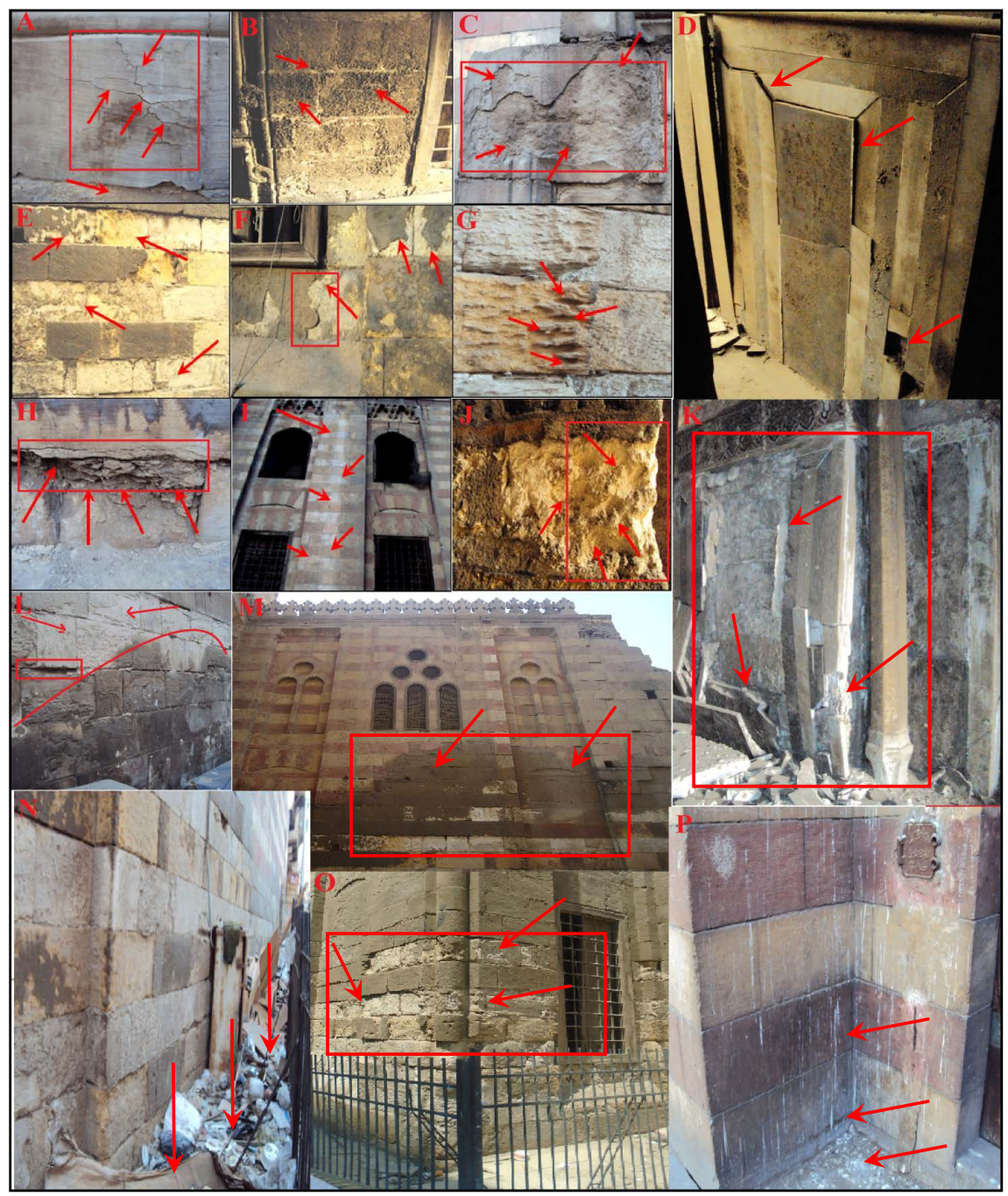

Figure 3. (A, C, E, F, H, I, P) Micro crack, separation to scaling in external layer, Peeling, erosion, loss of stone material of limestone and biological deterioration symptoms (The western south facade). (B) Soiling on the external surface of stone. (G, J, M, N, O) Alveolization, rounding, soiling, erosion, loss of stone material of limestone, and accumulation of rubbish next to the external façade (the eastern south facade). (D, K) Deterioration and fall down of marble casings (the southern wall of the shrine). 
properties tests were determined by standard test methods. Mineralogical compositions were determined by X-ray diffraction patterns, using a Philips X-ray $\mathrm{PW} 1840$ diffractometer with $\mathrm{Cu}-\mathrm{K} \alpha$ radiation generated at $40 \mathrm{kV}$ and $40 \mathrm{~mA}$. It covers $2 \theta$ from $5^{\circ}$ to $50^{\circ}$. Mineral composition investigations were done by XRD for defining the chemical composition of building materials samples using Philips X-Pert Pro X-ray diffractometer. The petrography study was carried out using ZEISS (Axio Imager. A1m) Polarized Light Microscopy (PLM), with an Axio Cam MRC5, under 20× magnification. The deteriorated samples were investigated using Olympus $\mathrm{B} \times 40$ optical stereo microscope, and recorded with digital camera under 40 - 60× magnification. Microstructure and chemical compositions were determined by JEOL JSM 5500 LV Scanning Electron Microscope (SEM) coupled with X-ray energy dispersive system (EDS). The physical, mechanical, mineralogical and chemical properties of building materials (limestone, marble, and mortars) used in Qanibay al-Rammah madrasa are examined as follows:

\subsection{Stones (Limestone and Marble)}

The investigation of a thin section of limestone samples under polarized light microscope (PLM) showed that all samples mainly consist of calcite, dolomite, and quartz, as minor minerals, addition to clay minerals, fossils, and iron oxides were found within grains. The interstitial spaces in limestone texture fill with a fine mosaic texture of calcite crystals, as well as the presence of fragments of quartz crystals and different types of fossils, such as Nummulite and Foraminifera fossils (Figure 4). The examination of limestone samples was carried out by Olympus $B \times 40$ optical stereo microscope, where roughening, relief in the stone surfaces, addition to granular disintegration into grains, crystallized salts, soiling and pitting were observed in all samples. The petrographic study of marble samples showed that all samples contain massive texture, micro-cracks, and rare crystals of quartz, anorthite, ankerite, chlorite, and biotite were observed in

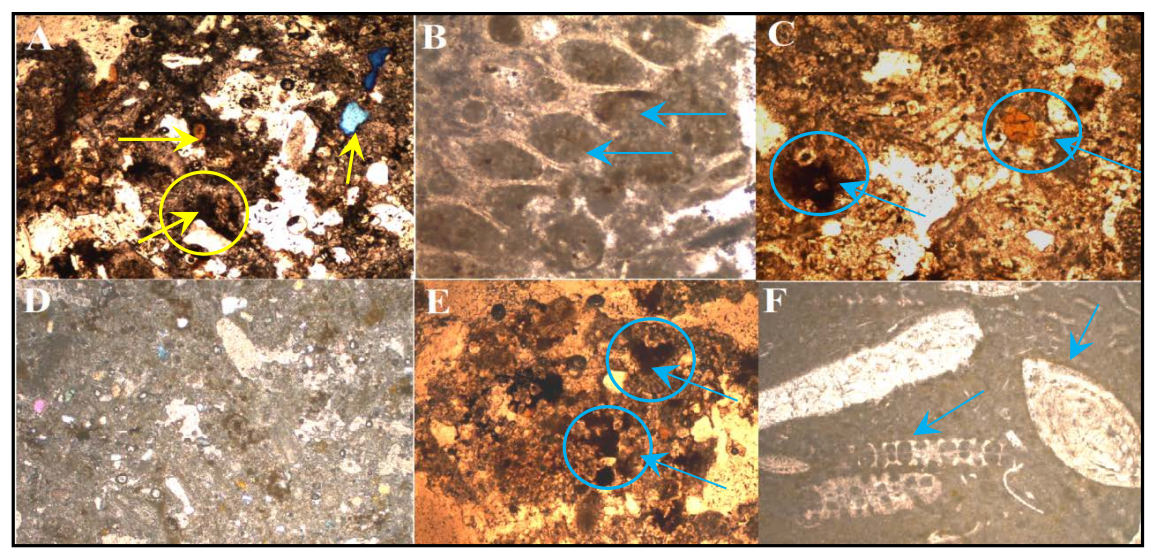

Figure 4. Investigation of thin section shows the presence of calcite with fine grained crystals lined with different iron oxides, in addition to presence nummulite microfossils, foraminifera and Bryozoa echinoid fossils. 
texture of all samples, as well as the presence mosaic texture was in most of marble samples (Figure 5). Limestone samples were investigated by SEM, showing micro cracks in internal structure of the stone, disintegration between calcite crystals and dense of halite and gypsum crystals which covers the pores of the stone, in addition to loss of binding materials, and erosion in calcite crystals. Deteriorated marble samples show white marble which consists of combined calcium carbonate with weak porosity, in addition to presence of fungi between grains, compact calcite crystals with a small percentage of salts showed in red marble samples, and heterogeneous calcite crystals with presence crystals of salts showed in green marble samples (Figure 6).

The limestone samples (L1 to L3) were investigated by XRD to determine the different mineral components of samples. All results are shown in (Table 2) and (Figure 7 and Figure 8), the results of the study show that the deteriorated limestone samples mainly consists of calcite $\left(\mathrm{CaCO}_{3}\right)$, dolomite $\left(\mathrm{Ca}, \mathrm{Mg}\left(\mathrm{CO}_{3}\right)_{2}\right)$, in addition to quartz $\left(\mathrm{SiO}_{2}\right)$, ankerite $\left(\mathrm{Ca}(\mathrm{Fe}, \mathrm{Mg}, \mathrm{Mn})\left(\mathrm{CO}_{3}\right)_{2}\right)$, as a minor minerals and halite $(\mathrm{NaCl})$, gypsum $\left(\mathrm{CaSO}_{4} \cdot 2 \mathrm{H}_{2} \mathrm{O}\right)$, hematite $\left(\mathrm{Fe}_{2} \mathrm{O}_{3}\right)$ as impurities.

$\mathrm{X}$-ray diffraction patterns of marble samples (M1 to $\mathrm{M} 3$ ) revealed that all samples mainly consist of calcite, dolomite $\left(\mathrm{Ca}, \mathrm{Mg}\left(\mathrm{CO}_{3}\right)_{2}\right)$, and Brucite $(\mathrm{Mg}$ $\left.(\mathrm{OH})_{2}\right)$ in close proportions, with moderate proportions of quartz $\left(\mathrm{SiO}_{2}\right)$, Anorthite $\left(\mathrm{CaAl}_{2} \mathrm{Si}_{2} \mathrm{O}_{8}\right)$, chlorite $\left(\mathrm{HClO}_{2}\right)$, ankerite $\left(\mathrm{Ca}(\mathrm{Fe}, \mathrm{Mg}, \mathrm{Mn})\left(\mathrm{CO}_{3}\right)_{2}\right)$, and biotite $\left(\mathrm{K}(\mathrm{Mg}, \mathrm{Fe})_{3}\left(\mathrm{AlSi}_{3} \mathrm{O}_{10}\right)(\mathrm{F}, \mathrm{OH})_{2}\right)$.

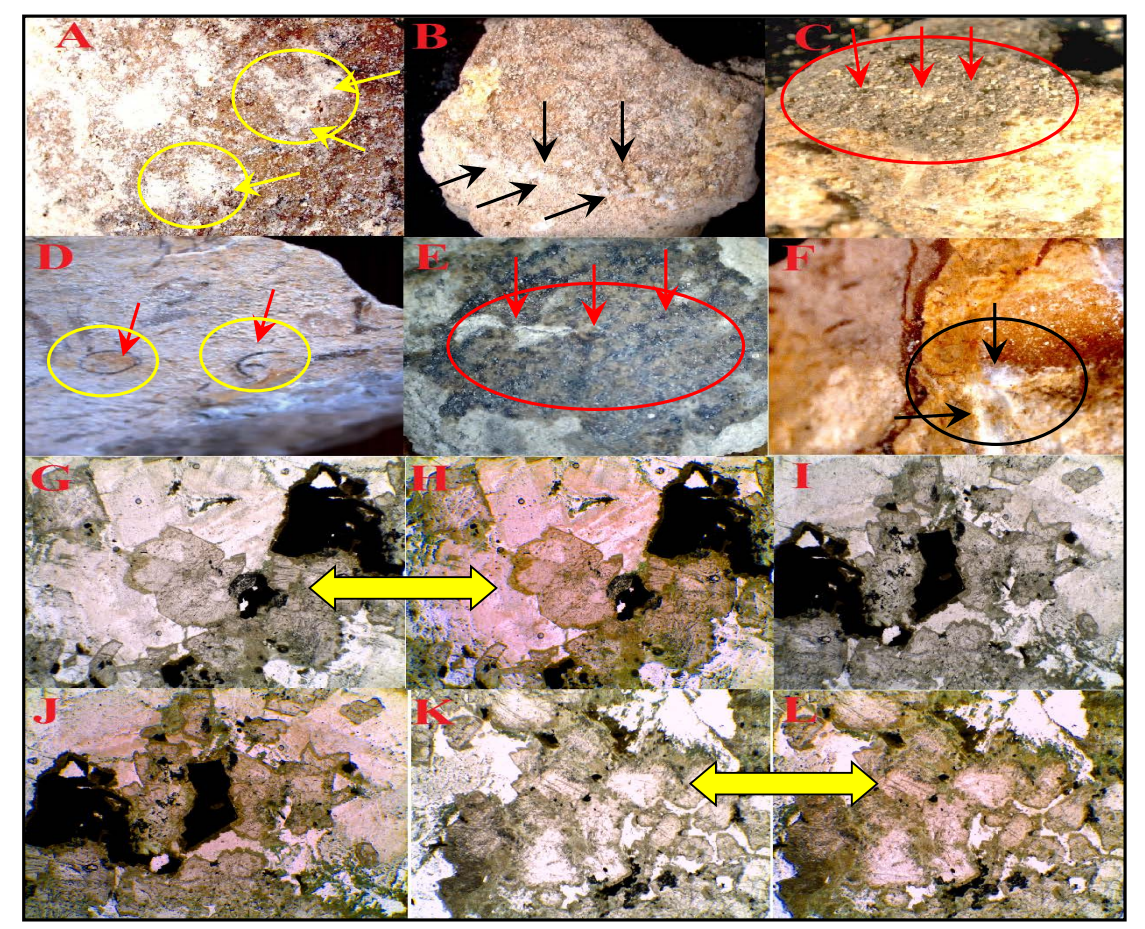

Figure 5. (A-F) Represent the limestone samples that invistegated by optical stereo microscope, which show roughening and relife in the stone surfaces, addition to granular disintegration into grains, crystallized salts, soiling and pitting were observed in all samples, fossiles shows in D sample. (G-L) Show thin section of the marble samples show compact mosaic texture, coarse grained crystals, cleavege, and micro cracks in the texture. 


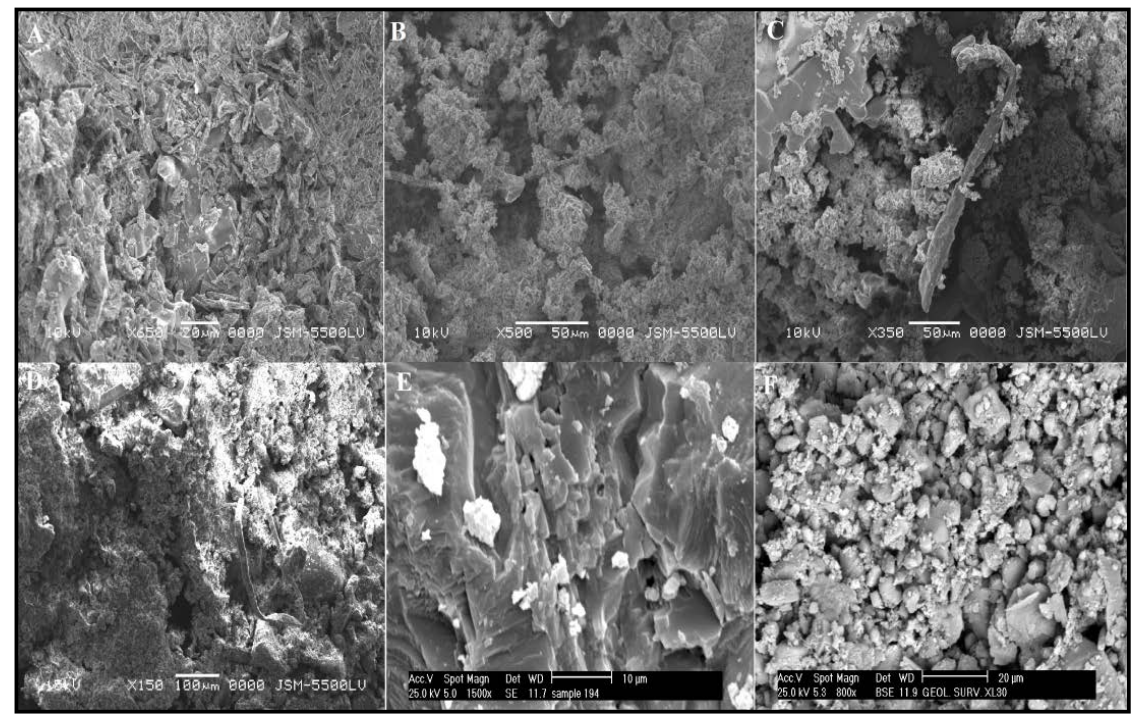

Figure 6. (A, B, C) SEM Photographs of deteriorated limestone samples. (A) Shows the deterioration of mineral crystals, and crystalline sulfur salts (650x); (B) Loss of binding materials and crystalline salts (500x); (C) Shows damage of calcitecrystals and loss of bonding materials and corrosion of mineral crystals $(350 \times)$. (D, E, F) SEM Photographs of deteriorated marble samples. (D) Shows white marble that consists of combined calcium carbonate with weak porosity, in addition to presence of fungi between grains (150x); (E) Shows red marble which consists of compact calcite crystals with a small percentage of salts $(1500 \times)$; (F) Shows green marble which consists of heterogeneous calcite crystals with presence crystals of salts $(800 \times)$.

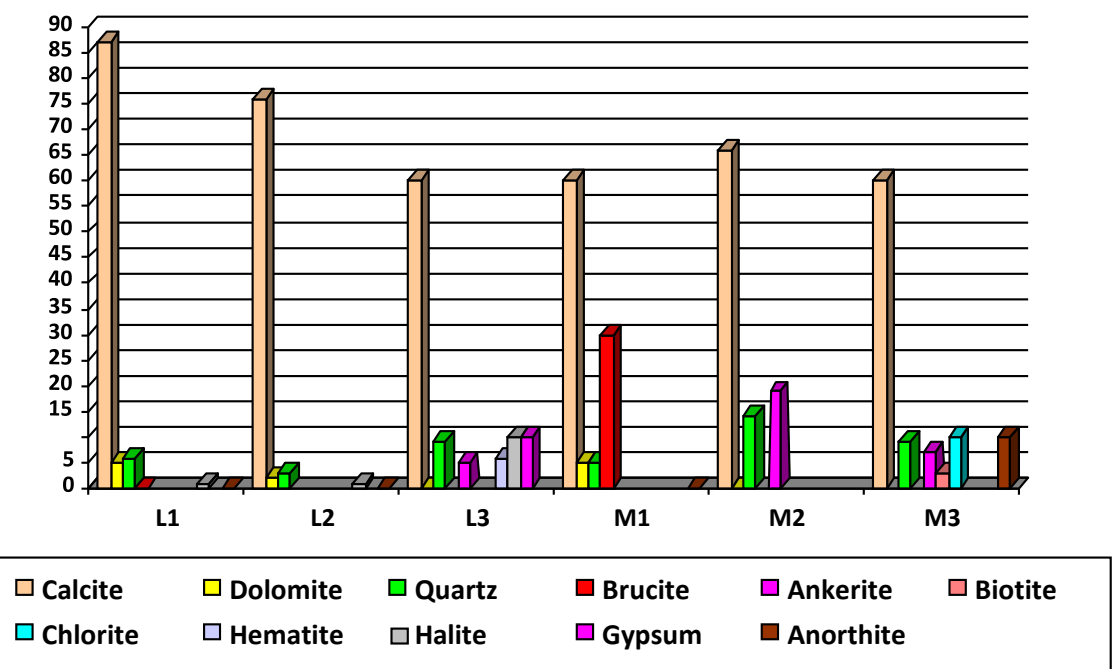

Figure 7. Comparison of X-ray diffraction analysis results of limestone and marble samples.

Table 2. X-ray diffraction analysis results of limestone and marble samples.

\begin{tabular}{cccccccccccc}
\hline \multirow{2}{*}{ Samples } & $\begin{array}{c}\text { Cal. } \\
\%\end{array}$ & $\begin{array}{c}\text { Dol. } \\
\%\end{array}$ & $\begin{array}{c}\text { Qu. } \\
\%\end{array}$ & $\begin{array}{c}\text { Bru. } \\
\%\end{array}$ & $\begin{array}{c}\text { Ank. } \\
\%\end{array}$ & $\begin{array}{c}\text { Bio. } \\
\%\end{array}$ & $\begin{array}{c}\text { Ano. } \\
\%\end{array}$ & $\begin{array}{c}\text { Chl. } \\
\%\end{array}$ & $\begin{array}{c}\text { Hem. } \\
\%\end{array}$ & $\begin{array}{c}\text { Hal. } \\
\%\end{array}$ & $\begin{array}{c}\text { Gyp. } \\
\%\end{array}$ \\
\hline L1 & 87 & 5 & 6 & - & - & - & - & - & - & 1 & - \\
L2 & 76 & 3 & 2 & - & - & - & - & - & - & 8 & \\
\hline
\end{tabular}




\section{Continued}

\begin{tabular}{llllllllllll}
\hline L3 & 60 & - & 9 & - & 5 & - & - & - & 6 & 10 & 10 \\
M1 & 60 & 5 & 5 & 30 & - & - & - & - & - & - & - \\
M2 & 66 & - & 14 & - & 19 & - & - & - & - & - & - \\
M3 & 60 & - & 9 & - & 7 & 3 & 10 & 10 & - & - & - \\
\hline
\end{tabular}
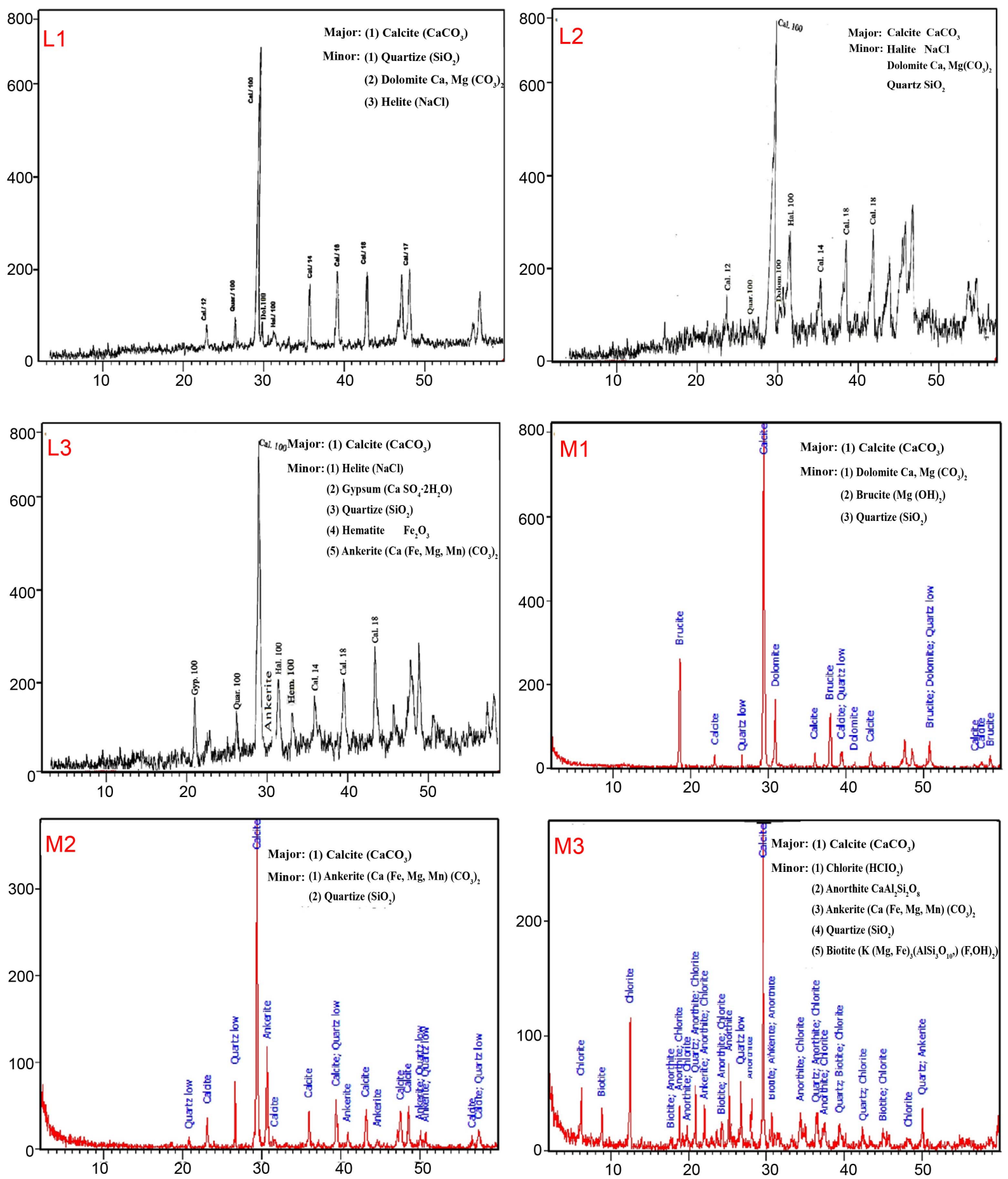

Figure 8. X-ray diffraction patterns of limestone and marble samples. 
Through results of XRD analysis of limestone samples we observed that the limestone used in the building contains many of the products of damage such as gypsum due to interaction of air pollution gases with limestone components, presence of halite salts due to effect of contaminated ground water, when a large amount of this salt is presented in stone's pores physiochemical effects on building materials occur, in addition to presence of iron oxides which are facilitated weathering of building materials of Qanibay al-Rammah madrasa, resulted to presence several deterioration aspects on stone surfaces such as, roughening, relief, calcined salts, and hard black crust due to effect of air pollution, in addition to granular disintegration into grains, loss of stone materials, peeling, exfoliation, and bleeding of stone.

The physical and mechanical properties tests were carried out by standard test methods (ASTM) to determine the physical (bulk density, water absorption, porosity), mechanical properties of limestone and marble samples which are represented different places of the case study.

Limestone and marble samples were cut into cubes $5 \times 5 \times 5 \mathrm{~cm}$, that were then subjected to physical and mechanical properties tests. Then, the average of the cubes test readings were taken separately, as shown in Table 3, Table 4.

The results of physical properties of the deteriorated samples explain that there is increase in porosity, water absorption and decrease in the density, in particular the limestone samples which contained on high concentrations of mineral salts, clay minerals and iron oxides, also all the deteriorated samples have been decreased in its mechanical properties.

Table 3. Shows the physical properties of limestone and marble samples.

\begin{tabular}{cccc}
\hline Sample & Density $(\mathrm{cm})^{3}$ & Porosity \% & Water adsorption\% \\
\hline L1 & 2.03 & 16.08 & 12.27 \\
L2 & 1.98 & 18.12 & 12.25 \\
L3 & 1.87 & 19.65 & 17.60 \\
M1 & 2.20 & 15.17 & 10.14 \\
M2 & 1.95 & 17.70 & 13.23 \\
M3 & 2 & 16.10 & 12.15 \\
\hline
\end{tabular}

Table 4. Shows the mechanical properties of limestone and marble samples.

\begin{tabular}{ccc}
\hline Sample & Dimensions $(\mathrm{cm})$ & Compressive strength $\left(\mathrm{kg} / \mathrm{cm}^{2}\right)$ \\
\hline L1 & $5 \times 5 \times 5$ & 112 \\
L2 & $5 \times 5 \times 5$ & 98 \\
L3 & $5 \times 5 \times 5$ & 95 \\
M1 & $5 \times 5 \times 5$ & 115 \\
M2 & $5 \times 5 \times 5$ & 111 \\
M3 & $5 \times 5 \times 5$ & 113 \\
\hline
\end{tabular}




\subsection{Mortars}

There are two mortars (lime-gypsum) used as binding materials in the joints of stones' courses. Mortars samples were investigated by SEM, the lime mortar samples showed calcium carbonate with an abundance of sand which used as a filler material, the examination shows the presence of fine particles of calcite and quartz, in addition to hematite, feldspar, and gypsum as minor minerals. The second kind of mortars used in case study is gypsum mortar, where it was investigated by SEM, which showed aggregates of gypsum with particles of calcite and quartize. From examination showed disintegration of mortar crystals due to loss of bonding materials, which led to appearance of voids and disassembled particles, this is due to the effect of groundwater on building materials (Figure 9).

$\mathrm{X}$-ray diffraction patterns of mortars samples revealed that the lime mortar mainly consist of calcite, quartize, hematite and feldspar, where presence of hematite and feldspar indicate on use of red brick powder between the components of the lime mortar. Investigated gypsum mortar by XRD showed it consist of quaritze and gypsum as major minerals, in addition to minor minerals of calcite (Figure 10 and Table 5).
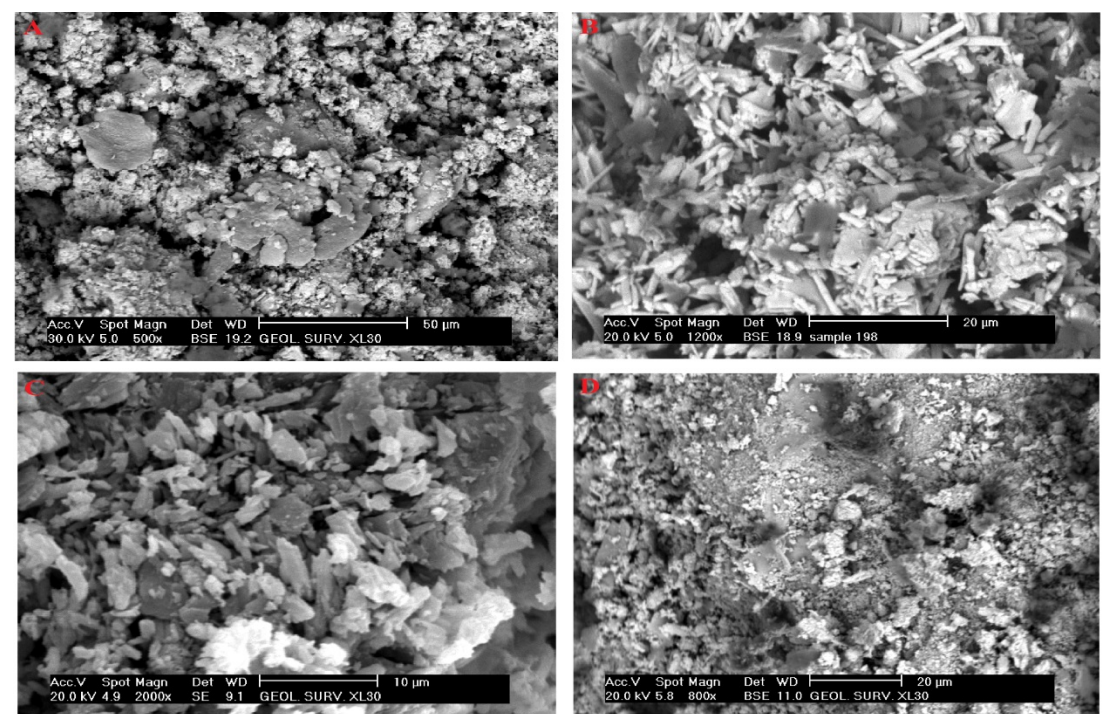

Figure 9. SEM Photographs of mortars used in Qanibay al-Rammah madrasa. Lime mortar (A, D) show presence crystals of calcite with an abundance of sand, from photographs show disintegration the mineral crystals due to loss of bonding materials. Gypsum mortar (B, C) show crystals of gypsum with aggregats of quartize, in addition to particales of calite.

Table 5. X-ray diffraction analysis results of lime and gypsum mortars samples.

\begin{tabular}{ccccccc}
\hline Samples & Calcite & $\begin{array}{c}\text { Gypsum } \\
\%\end{array}$ & $\begin{array}{c}\text { Quartz } \\
\%\end{array}$ & $\begin{array}{c}\text { Hematite } \\
\%\end{array}$ & $\begin{array}{c}\text { Halite } \\
\%\end{array}$ & $\begin{array}{c}\text { Feldspar } \\
\%\end{array}$ \\
\hline L.M1 & 56 & - & 24 & 12 & - & 8 \\
L.M2 & 42 & 51 & - & - & 7 & - \\
G.M1 & 15 & 32 & 53 & - & - & - \\
G.M2 & 12 & 27 & 61 & - & - & - \\
\hline
\end{tabular}



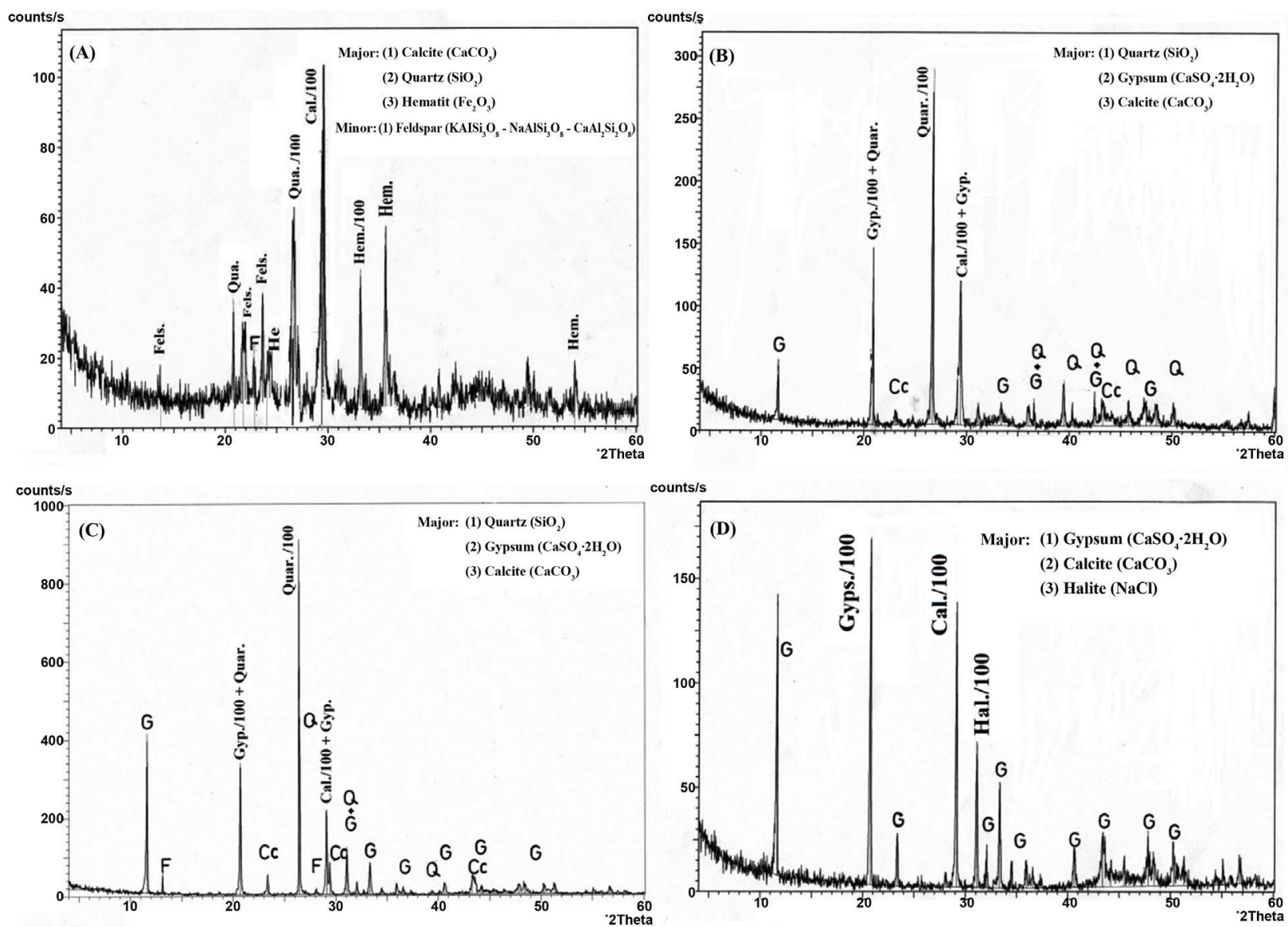

Figure 10. X-ray diffraction patterns of (lime (A, D)-Gypsum (B, C)) mortars samples.

\section{Evaluate of the Structural Behavior of the Building under Seismic Loads}

An intermediate earthquake took place near Dahshur, Egypt, about $20 \mathrm{~km}$ south of Cairo, on 12 October 1992, the earthquake's strength was between 6 and 7 on the Richter scale. This earthquake combined with other large earthquakes have affected Qanibay al-Rammah madrasa, but the recent earthquake may have caused a large amount of damage because of poor structural conditions of the building (Figure 11) [28].

3D numerical model of Qanibay al-Rammah madrasa was carried out using the finite elements (FE) SAP 2000 software to determine the structural behavior of the build under self-weight and earthquakes loads. Data of building materials properties have been entered into SAP 2000 software.

Earthquakes loads were calculated in two orthogonal directions (X-X) and (Y-Y), structural elements were represented with consideration that the walls and roofs as shell elements, arches as frame element and the pillars as a hinged support.

\subsection{The Shear Force Affecting the Building}

The shear force is represented the force that affects in a perpendicular direction 


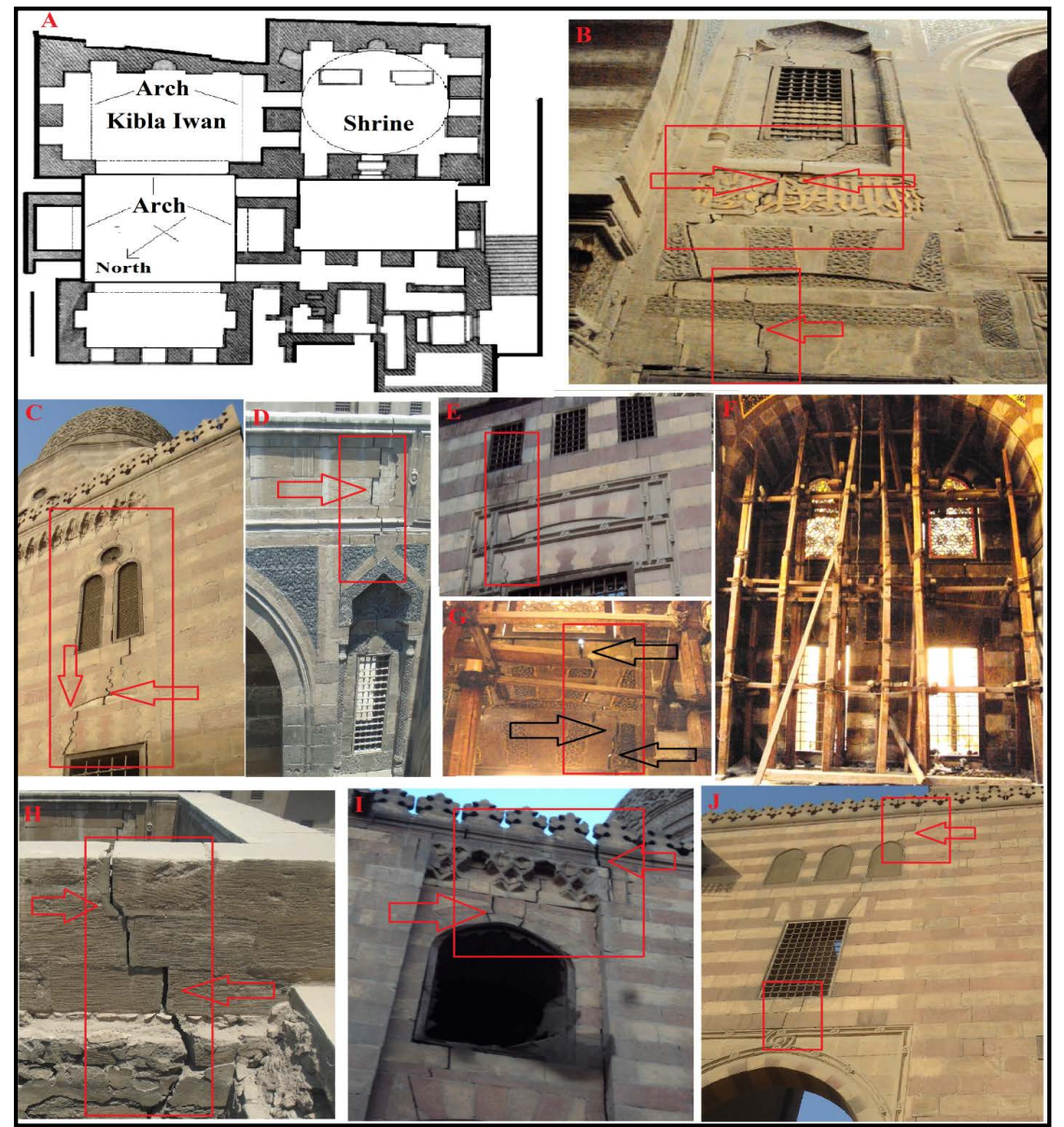

Figure 11. (A) Horizontal design of Qanibay al-Rammah madrasa; (B) J. showing cracks with different size in different places of the building.

on the section. The permissible shear force was calculated by the following equation:

$$
\begin{gathered}
\text { Qal }=0.20 \mathrm{n} / \mathrm{mm}^{2} \\
\text { (Shear force according to the Egyptian building code) } \\
Q=F / b \cdot d(Q=\text { shear force value, } \\
b=\text { Section width, } d=\text { depth, } F=\text { affected force). } \\
0.20=F / 1 \times 700 \& F=0.20 \times 700=140 \mathrm{~N} .
\end{gathered}
$$

The shear force resulting from earthquakes force affects the building in two directions (X-X) and (Y-Y). From the resultant deformations in Figure 11 showing that the areas most exposed to high shear strength more than the allowable value were in the upper parts of the east wall of the kiblah Iwan, when the shear force was parallel to the section in direction (Y-Y), and when it was perpendicular on the section in direction (X-X) the lower parts of the wall are the most affected by shear force stresses (Figure 12(A), Figure 12(B)).

\subsection{The Bending Moment Affecting the Building}

Tensile stresses affecting the building were calculated in two axes $\mathrm{Y}$ and $\mathrm{X}$. These 

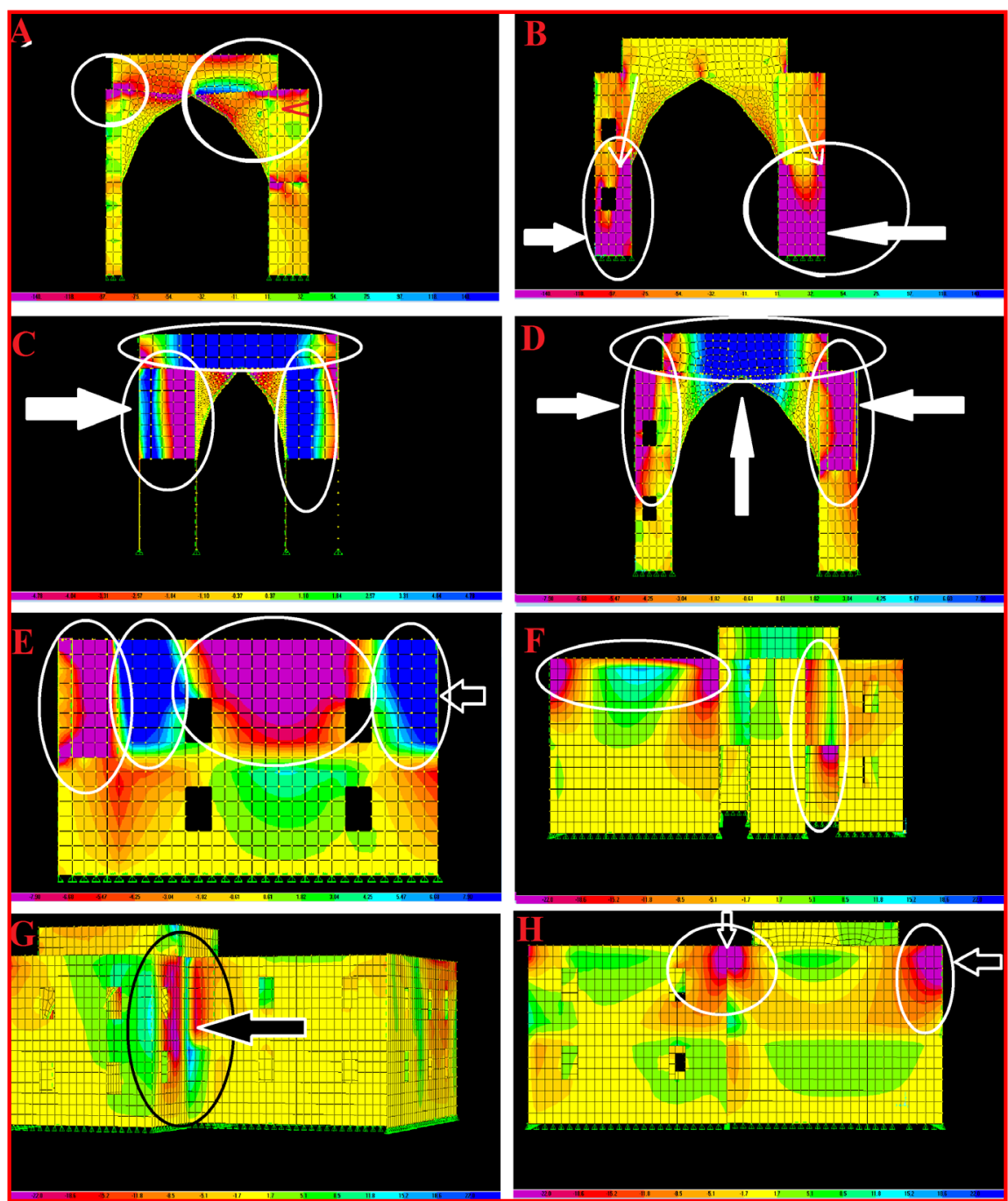

Figure 12. (A) The paralleled shear force to the section due to affected earthquakes force in the direction of $(\mathrm{X}-\mathrm{X})$. (B) The effect of the parallel shear force of the section in the direction (Y-Y). (C) (D) The bending moment affecting the section in the direction (X-X) and (Y-Y) (the east Iwan of great Iwan). (E) The bending moment affecting the eastern wall of the shrine. (F) The bending moment affecting the eastern wall of the building in the direction $(\mathrm{X}-\mathrm{X})$. (G) The bending moment affecting the eastsouth facade in the direction $(\mathrm{X}-\mathrm{X})$. (H) The bending moment affecting the westsouth facade in the direction $(\mathrm{X}-\mathrm{X})$.

stresses are considered the cause in cracks and collapse in most buildings, if the bending moment exceeds the allowable value. The building was designed by the PROKON software to identify critical places, where we reached the following results:

M11 (in direction $(\mathrm{X}-\mathrm{X}))=4.78 \mathrm{kn} \cdot \mathrm{m}$ and $\mathrm{M} 22($ in $\operatorname{direction}(\mathrm{Y}-\mathrm{Y}))=29 \mathrm{kn} \cdot \mathrm{m}$

The allowable value of bending moment was $4.78 \mathrm{Kn} \cdot \mathrm{m}$ in direction (X-X), and $29 \mathrm{Kn} \cdot \mathrm{m}$ in direction (Y-Y), so any increase in bending moment about the allowable value leads to cracks and collapse in the building.

Through results of structural analysis showed the critical and vulnerable plac- 
es in the building due to effect of the earthquakes are as follows;

- The east northern arch of the great Iwan (Figure 12(C), Figure 12(D)).

- The upper parts of corners and the middle-upper part from the east northern wall of the shrine (Figure 12(E)).

- The upper parts of corners of the west southern facade of the shrine (Figure 12(E)).

- The upper parts of corners of the east northern facade of great Iwan (Figure $12(\mathrm{H}))$.

\section{Results and Discussion}

Weathering forms on building materials which used in the case study were identified and classified according to four groups of weathering forms (Figure 2 and Table 1). The study concluded that the weathering forms represent an important parameter for the characterization, quantification, and evaluation of building materials deterioration where it was found that weathering forms of building materials used in the case study rang from very slight damage to very severe damage depending on its various properties and the damage intensity.

We observed the building materials used in the southern partition of the building such as the southern east façade, the southern east iwan and the shrine contain advanced stages of various deterioration symptoms, due to that this part of the building has been subjected to greater damage factors since the time of construction until at the moment, while rest of the madrasa was reconstructed after that it was ruined (Figure 13) [29] [30].

The investigations of building materials were performed by polarized light

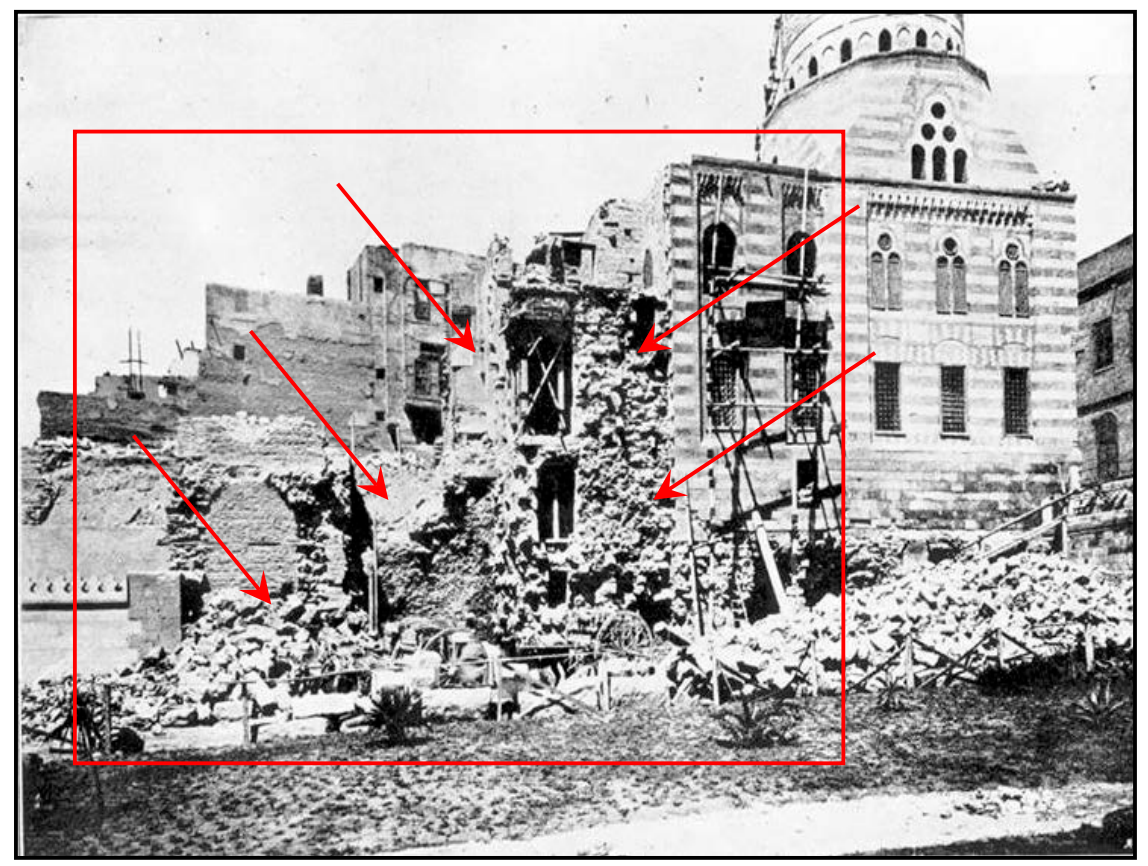

Figure 13. Qanibay al-Rammah complex, the western north iwan, part of the western south iwan and minaret are ruined. 
microscope (PLM), stereo microscope, scanning electron microscope (SEM), $\mathrm{X}$-ray diffraction (XRD), physical and mechanical properties tests.

The examination showed all limestone samples are mainly consists of calcite, quartz, in addition to ankerite, as a minor minerals, and halite, gypsum, and hematite as impurities. Clay minerals, fossils, and iron oxides were found within grains. From photographs show that the interstitial spaces in limestone texture fill with a fine mosaic texture of calcite crystals, as well as the presence of fragments of quartz crystals and different types of fossils, such as Nummulite and Foraminifera fossils. Micro cracks in internal structure of the stone, disintegration between calcite crystals, dense of halite and gypsum crystals which covers the pores of the stone, in addition to loss of binding materials, and erosion in calcite crystals were observed from exanimated samples.

The investigations showed that all marble samples contain of massive texture, micro cracks, and rare crystals of quartz. Anorthite, ankerite, chlorite, and biotite were observed in texture of all samples; in addition to the presence mosaic texture was in most of marble samples.

From examination showed occurrence disintegration of mortar crystals due to loss of bonding materials, which led to appearance of voids and disassembled particles, because of groundwater effects on building materials.

The results of physical properties of the deteriorated samples revealed that there are increase in porosity, water absorption and decrease in the density, in particular the samples which contained on high concentrations of mineral salts, clay minerals and iron oxides, also all the deteriorated samples have been decreased in its mechanical properties.

The investigations results indicated that the physical, chemical and mechanical properties of building materials played the main role with the surrounding environment factors in deterioration of building materials used in the case study.

The permissible shear force was calculated according to Egyptian building code, which was $140 \mathrm{~N}$, this means that if the force exceeds this value, the building will be exposed to cracks. From designed model by (F.E.M) was determined the critical places of Qanibay al-Rammah madrasa which is next the east northern arch of the great Iwan, the upper parts of corners, the middle-upper part from the east northern wall of the shrine, the upper parts of corners of the west southern facade of the shrine, and the upper parts of corners of the east northern facade of great Iwan. These places show different cracks with different size, due to effect the shear force of earthquakes (Figure 11 and Figure 12).

The bending moment in directions ( $\mathrm{X}$ and $\mathrm{Y}$ ) was calculated by PROKON software, the allowable value of bending moment was $4.78 \mathrm{Kn} \cdot \mathrm{m}$ in direction $(\mathrm{X}-\mathrm{X})$, and $29 \mathrm{Kn} \cdot \mathrm{m}$ in direction (Y-Y), this means that if the bending moment exceeds this value, the building will be exposed to cracks and collapse, where determined the critical places of Qanibay al-Rammah madrasa (Figure 12).

\section{Conclusions}

The building materials used in Qanibay al-Rammah madrasa have been affected 
by different deterioration factors. This study has attempted to make a contribution to determine the current state of building materials of Qanibay al-Rammah madrasa in two main fields, firstly by determining weathering forms on building materials, and secondly by different scientific techniques in laboratory.

The study concluded the stability of the building materials against the weathering strongly depends on their chemical, physical, mineralogical and petrographic properties, where the study results showed that the samples which contain on minerals salts, clay minerals, and iron oxides have more damage and decrease in its physical, mechanical properties.

From determining the critical places of Qanibay al-Rammah madrasa we can appropriate supporting methods to these places whether in the direction (X-X) or the direction (Y-Y).

The study results give way to us to identify the current state of Qanibay al-Rammah madrasa (as a procedure precedes the restoration) to find the appropriate method to the intervention with improving the building materials properties and reinforcement of structural elements subjected to cracks and supporting the places exposed to a high bending moment and shear force.

\section{Acknowledgements}

I would like to thank Eng. Barakat Heshmat Mohamed, consultant of the civil engineering of Gamaan office for engineering consultancy and geotechnical laboratories, Kingdom of Saudi Arabia for his cooperation and valuable efforts in this research.

\section{Conflicts of Interest}

The author declares no conflicts of interest regarding the publication of this paper.

\section{References}

[1] Klemm, R. and Klemm, D.D. (2013) Steine und Steinbrüche im alten Ägypten. Springer-Verlag, Berlin.

[2] Gulotta, D., Tedeschi, C., Binda, L. and Toniolo, L. (2008) Durability of Porous Material to Salt Decay. 11 th International Congress on Deterioration and Conservation of Stone Wydawnictwo Naukowe, Uniwersytetu Mikolaja Kopernika, 129-136.

[3] Grossi, C.M. and Brimblecombe, P. (2007) Effect of Long-Term Changes in Air Pollution and Climate on the Decay and Blackening of European Stone Buildings. Geological Society, London, Special Publications, 271, 117-130. https://doi.org/10.1144/GSL.SP.2007.271.01.13

[4] Khalaf, M.K. and Abdelmegeed, M.M. (2018) Assessment of Physical and Mechanical Characteristics of Masonry Building Materials in Historic Military Towers in Alexandria-Egypt: A Case Study. International Journal of Conservation Science, 9 , 677-688.

[5] El-Gohary, M.A. (2010) Investigations on Limestone Weathering of El-Tuba Minaret El Mehalla, Egypt: A Case Study. Mediterranean Archaeology and Archaeometry, 10, 61-79. 
[6] Steiger, M., Charola, A.E. and Sterflinger, K. (2011) Weathering and Deterioration. In: Siegesmund, S. and Snethlage, R., Eds., Stone in Architecture, Springer, Berlin, Heidelberg, 227-316. https://doi.org/10.1007/978-3-642-14475-2_4

[7] Fassina, V. (1991) Pollution atmospherique et alteration de la pierre, La degradation et la conservation de la pierre, 91.

[8] Abd Elhady, M. (1997) Scientific Studies in Restoration and Conservation of Inorganic Monuments. Zahra el Shark Library.

[9] Charola, A.E. (2000) Salts in the Deterioration of Porous Materials: An Overview. Journal of the American Institute for Conservation, 39, 327-343. https://doi.org/10.1179/019713600806113176

[10] Doehne, E. (2002) Salt Weathering: A Selective Review. Geological Society, London, Special Publications, 205, 51-64. https://doi.org/10.1144/GSL.SP.2002.205.01.05

[11] Přikryl, R. and Smith, B.J. (2007) Building Stone Decay: From Diagnosis to Conservation. Geological Society of London, London.

[12] Abd Elhady, M. (1995) Ground Water and the Deterioration of Islamic Building in Egypt. The Conference of the Restoration and Conservation of Islamic Monuments in Egypt, AUC, 118.

[13] Jain, A., Bhadauria, S., Kumar, V. and Chauhan, R.S. (2009) Biodeterioration of Sandstone under the Influence of Different Humidity Levels in Laboratory Conditions. Building and Environment, 44, 1276-1284.

https://doi.org/10.1016/j.buildenv.2008.09.019

[14] Collepardi, M. (1990) Degradation and Restoration of Masonry Walls of Historical Buildings. Materials and Structures, 23, 81-102.

https://ink.springer.com/article/10.1007/BF02472568 https://doi.org/10.1007/BF02472568

[15] Mohamed, E. (2019) 3D Finite Elements Technique for Collapse Causes of the Pylons in Egyptian Temples: A Study of the Great Pylon of Ramesseum Temple, Luxor, Egypt. Open Journal of Geology, 9, 1022-1041. https://doi.org/10.4236/ojg.2019.913103

[16] Park, H.D. and Shin, G.H. (2009) Geotechnical and Geological Properties of Mokattam Limestones: Implications for Conservation Strategies for Ancient Egyptian Stone Monuments. Engineering Geology, 104, 190-199.

https://doi.org/10.1016/j.enggeo.2008.10.009

[17] Rovnaníková, P. (2007) Environmental Pollution Effects on Other Building Materials. WIT Press, Southampton, 217-247. https://doi.org/10.2495/978-1-84564-032-3/07

[18] Mohamed, E.H. (2019) Using of GIS Technology for Conservation of the Ottoman Bathroom and Its Urban Surrounding in Qena-Egypt. Archaeological Discovery, 8, 26-46. https://doi.org/10.4236/ad.2020.81002

[19] Mohamed, E.H. (2019) The Effect of the Reciprocal Relations of the Deterioration Symptoms in Different Building Materials in Some of historic Cairo's Buildings. Resourceedings, 2, 167-184.

https://www.press.ierek.com/index.php/Resourceedings/article/view/612 https://doi.org/10.21625/resourceedings.v2i2.612

[20] Siegesmund, S., Weiss, T. and Vollbrecht, A. (2002) Natural Stone, Weathering Phenomena, Conservation Strategies and Case Studies: Introduction. Geological Society, London, Special Publications, 205, 1-7. https://doi.org/10.1144/GSL.SP.2002.205.01.01 
[21] El-Gohary, M. (2011) Chemical Deterioration of Egyptian Limestone Affected by Saline Water. International Journal of Conservation Science, 2, 17-28.

[22] El-Hady, A. (1995) Ground Water and the Deterioration of Islamic Buildings in Egypt. In: Bacharach, J.L., Ed., The Restoration and Conservation in Islamic Monuments in Egypt, 115-116.

[23] Mohamed, E.H. (2014) The Conservation Methods of Archaeological Buildings Situated within Urban Surroundings in Cairo, with Application on Case Studies of the Archaeological, Islamic Buildings Located Saladin's Square. Ph.D. Thesis, Faculty of Archaeology, South Valley University, Egypt.

[24] Gupta, S.P. and Sharma, K. (2012) The Role of Fungi in Biodeterioration of Sandstone with Reference to Mahadev Temple, Bastar, Chhatisgarh. Recent Research in Science and Technology, 4, 18-21.

http://updatepublishing.com/journal/index.php/rrst/article/view/878

[25] Palla, F. (2005) Biotechnologies for Characterization of Bioaerosol in Indoor Environments for Cultural Heritage. In: Congresso Nazionale AI Ar., PATRON, 83-90.

[26] Moroni, B. and Pitzurra, L. (2008) Biodegradation of Atmospheric Pollutants by Fungi: A Crucial Point in the Corrosion of Carbonate Building Stone. International Biodeterioration \& Biodegradation, 62, 391-396. https://doi.org/10.1016/j.ibiod.2008.03.011

[27] Abdelmegeed, M.M., Badogiannis, S., Kotsovos, G. and Vougioukas, E. (2014) Assessment of Physical and Mechanical Properties of Historical and Traditional Masonry Buildings: A Case Study. International Journal of Conservation Science, 5, 343-354.

[28] Sykora, D., Look, D., Croci, G. and Karaesmen, E. (1993) Reconnaissance Report of Damage to Historic Monuments in Cairo, Egypt Following the October 12, 1992 Dahshur Earthquake. Army Engineer Waterways Experiment Station Vicksburg MS Geotechnical Lab. https://apps.dtic.mil/docs/citations/ADA325190

[29] Farghali, A. (2001) The Brief Guide to the Most Important Islamic and Coptic Monuments in Cairo, the Egyptian-Lebanese House.

[30] Abdel-Wahab, H. (1993) History of Archaeological Mosques. 2nd Edition, Oriental Papers for Printing and Publishing. 